\title{
A Numerical Example Showing Globally Welfare- Worsening Liberalization of International Trade in Banking Services
}

Ngee Choon Chia, National University of Singapore

\author{
John Whalley, University of Western Ontario, London, \\ Canada, and National Bureau of Economic Research, \\ Cambridge, Massachusetts
}

\begin{abstract}
This paper argues that the analytical basis for the desirability of free trade in services may be more fragile than many have realized. We use an explicit intertemporal international trade general equilibrium model to analyze the consequences of trade liberalization covering banking services. In this model, these services allow gains from trade to be exploited, but do not directly enter preferences. We construct a numerical example in which all consumers in both countries are made unambiguously worse off with free trade in banking services compared to an equilibrium with no trade in banking. The implication we draw from our analysis is that free international trade in banking services need not be preferred from a global efficiency point of view to autarky in an intertemporal, international trade, general equilibrium model, in which there is costly intertemporal intermediation. (C) Society for Policy Modeling, 1997
\end{abstract}

\section{INTRODUCTION}

Liberalization of trade in services has become central to the GATT Uruguay Round negotiations (yet to conclude at time of writing). The theme underlying much of the discussion is that global free trade in services, as with goods, is desirable, as in McCulloh's (1990) argument that liberalizing trade in services will be necessary to maintain forward liberalizing momentum beyond the Uruguay Round. And, in a recent theoretical paper, Jones and Ruane (1990) have come to the conclusion that opening up

Address correspondence to Dr. John Whalley, Department of Economics, University of Western Ontario, London, ONT, N6A 5CA Canada.

Received December 1994; final draft accepted May 1995. 
trade in either service factors or service products will unambiguously improve welfare for a country, independent of a country's relative factor endowments and whether or not it has a comparative advantage in services. Thus in both the policy and academic communities, liberalization in services, like goods, is generally thought to be good. ${ }^{1}$

This paper argues that the analytical basis for the desirability of free trade in services may be more fragile than many have realized. In particular, we suggest that existing literature does not take into account characteristics of particular service items, and a general discussion of the desirability of free trade in services may therefore be misdirected. The various categories that make up services (transportation, trans-border data flows, banking, insurance, tourism, engineering and consulting services, and others) involve different forms of intermediation, risk pooling, and other activities, and there seems no particular reason why general propositions as to the desirability of free trade will automatically hold for all of these. The characteristics of each need to be taken into account in order to analyze the effects of potential trade liberalization. ${ }^{2}$

We make this argument by focusing on potential liberalization of trade in banking services. In our approach, these services do not themselves directly enter preferences, because it is only commodities purchased with the financing obtained that directly affect any individual's welfare. Individuals with identical consumption of other goods get the same utility from, say, a car whether it is debt financed or whether purchased with cash. The use of intermediation services to arrange the financing for a car, in and of itself, does not directly provide utility. Financial intermediation services bring together borrowers and lenders and facilitate intertemporal trade, but they require real resources.

We use an explicit intertemporal international trade general equilibrium model to analyze the consequences of trade liberalization covering banking services. In this model, these services allow

\footnotetext{
${ }^{1}$ Melvin (1989), however, has argued that there is a need to interpret comparative advantage more carefully when services are incorporated into a Heckscher-Ohlin model, and finds that tariffs and other commercial policies may have different effects from those conventionally analyzed. Melvin, however, discusses producer services, whereas we are specifically interested here in intermediary services.

${ }^{2}$ Hindley and Smith (1984), suggest that the same theoretical models can be used to analyze trade in goods or services, a position we differ from here.
} 
gains from trade to be exploited, but do not directly enter preferences. Somewhat similar general equilibrium models incorporating transactions costs were developed some 20 years ago by Foley and others (Foley, 1970). They differ from the standard ArrowDebreu model, which underlies conventional Heckscher-Ohlin trade theory and standard analysis of the gains from trade in that the resource endowment of the economy is effected by the volume of trade.

We then use a two-period two-country version of this model to construct a numerical example in which all consumers in both countries are made unambiguously worse off with free trade in banking services compared to an equilibrium with no trade in banking. In the model there is both international and intertemporal trade, and intermediation services are used in each country. Free international trade in goods occurs in both periods; but under autarky in banking services, all intermediation services used within a country are provided by financial institutions located in that country. With liberalized international trade in banking, the country with comparative advantage in banking services provides these services to both countries. The effect is to increase the use of intermediation services. While this facilitates gains from intertemporal trade, more real resources are required to provide the increased intermediation services and, hence, the net effect on welfare can be negative. This is shown by a numerical example. We also report a further example in which all consumers are better off under liberalization in banking services to help emphasize that we do not claim generality for this first result. Our point is simply that such liberalization may not be welfare improving.

The implication we draw from our analysis is that free international trade in banking services need not be preferred from a global efficiency point of view to autarky in an intertemporal, international trade, general equilibrium model, in which there is costly intertemporal intermediation. The analytical underpinnings of the current GATT negotiations on services, at least as far as banking services are concerned, may thus be more frail than currently recognized.

\section{THE THEORETICAL FRAMEWORK}

The numerical examples we report later to show that trade liberalization in banking services can result in a globally welfareworsening change are derived using a simple intertemporal international trade equilibrium model with transactions costs, based 
on an equilibrium formulation with transactions costs developed over 20 years ago by Foley (1970). ${ }^{3}$ The model we use assumes that there are two countries, indexed by $k=a, \beta$. Each of these faces a finite number of periods, and has a finite number of agents (two of each in our examples). There are $m_{k}$ individuals in each country indexed by $i=1, \ldots, m_{k}$. All individuals are endowed with initial stocks of time-dated consumption goods, indexed by $j=1, \ldots, n$. Aggregate endowments in each period are finite. All agents are assumed to live in all periods; that is, no overlapping generations structure is assumed.

For simplicity we assume a pure exchange model with no production, in which each agent has preferences and endowments of time-dated consumption goods. In the model, agents can trade time-subscripted goods, but to do so they must use intermediation services (for simplicity, these are assumed to be denominated in terms of time-subscripted goods). Unlike in a classical no-transactions-costs general equilibrium model, agents in this model do not trade directly with each other. All transactions are carried out through an intermediary, and intermediary services require real resources. The presence of intermediation costs drives a wedge between the buying and the selling price of any time-dated consumption good. In order for trade in banking services to occur under free international trade, we assume that in autarky there are different intermediation cost margins in the two countries. Intermediation cost margins are, however, the same for all timedated goods traded within each country. We assume, for simplicity, that buyers of any time-subscripted good bear the intermediation costs, so that even with no international trade in intermediation services, seller's prices of goods are equalized across countries.

We use the following notation to formally set out the model:

$w_{i j}^{k} \quad$ : endowment of good $j$ of individual $i$ in country $k$.

$c_{i j}^{k} \quad$ : consumption of good $j$ by individual $i$ in country $k$.

$z_{i j}^{k} \quad:$ net trade in good $j$ by individual $i$ in country $z_{i j}^{k}=\left(c_{i j}^{k}-w_{i j}^{k}\right) . z_{i j}^{k}>0(<0)$ indicates that individual $i$ is a buyer (seller) of good $j$.

$\lambda^{k} \quad$ : intermediation cost margin in country $k$.

$P_{j, s} \quad$ : selling price of good $j$.

$P_{j, b}^{k} \quad$ : buying price of good $j$ in country $k$.

$U_{i}^{k} \quad$ : preference ordering of individual $i$ in country $k$.

\footnotetext{
${ }^{3}$ See also the discussion in Ryan (1990) based on the Samuelsonian "iceberg" transportation cost formulation, with seemingly different conclusions.
} 
Each individual $i$ in country $k$ is assumed to have a preference ordering $U_{i}^{k}$ defined over all time-dated consumption goods (but not over intermediation services). The intertemporal utility maximization problem of each agent is:

$$
\operatorname{Max} U_{i}^{k}=U_{i}^{k}\left(c_{i l}^{k}, \ldots, c_{i n}^{k}\right)
$$

subject to

$$
\sum_{j} P_{j, b}^{k} \max \left(c_{i j}^{k}-\omega_{i j}^{k}, 0\right)+\sum_{j} P_{j, s} \min \left(c_{i j}^{k}-\omega_{i j}^{k}, 0\right) \leqslant 0
$$

Intermediation costs are assumed to be borne by buyers in each market, giving rise to a different buyer's price in each country, reflecting the fact that selling prices are common given free trade in goods.

$$
P_{j, b}^{k}=\left(1+\lambda^{k}\right) P_{j, s}
$$

From Equation 2,

$$
\sum_{j}(1+\lambda) P_{j, s} \max \left(c_{i j}^{k}-\omega_{i j}^{k}, 0\right)+\sum_{j} P_{j, s}^{k} \min \left(c_{i j}^{k}-\omega_{i j}^{k}, 0\right) \leqslant 0 .
$$

or

$$
\sum_{j} P_{j, s} c_{i j}^{k} \leqslant \sum_{j} P_{j, s} w_{i j}^{k}-\sum_{j} P_{j, s} \lambda^{k}\left(\max z_{i j}^{k}, 0\right)
$$

Equation 2 defines the budget set for individual $i$ in the dual price environment that the model implies. This is smaller than where there are no intermediation costs, because some of the endowment of each individual is used up in intermediation services.

Aggregating across all individuals yields a modified version of the Walras' law for each country $k$.

$$
\sum_{i} \sum_{j} P_{j, s} c_{i j}^{k}=\sum_{i} \sum_{j} P_{j, s} \omega_{i j}^{k}-\sum_{i} \sum_{j} P_{j, s} \lambda^{k} \max \left(z_{i j}^{k}, 0\right)
$$

In the absence of intermediation costs, Equation 6 collapses to the more familiar form of Walras' law.

In the absence of international trade in intermediation services, equilibrium in this model is characterized by a vector of sellers prices $P_{j, s}^{*}$ and a vector of time-dated consumption of goods by household, $<c_{i, j}^{k *}$, such that demand equals supply (i.e., endowments net of resource use through transactions costs) for every time-dated commodity, that is,

$$
\sum_{k} \sum_{j} c_{i j}^{k}-\sum_{k} \sum_{j} \omega_{i j}^{k}-\sum_{k} \sum_{j} \lambda^{k} \max \left(z_{i j}^{k}, 0\right)=0 .
$$

where the last term denotes resources used in transacting in $\operatorname{good} j$. 
In the presence of trade in banking services, agents in the country with the higher intermediation margin will use intermediation services provided by the other country, and complete specialization in intermediation services will occur. Equilibrium in the presence of intermediation costs and free international trade in banking services thus involves a vector of both buying and selling for goods $\left(P_{j, s}^{k *}, P_{j, s}^{*}\right)$, the latter of which are common to both countries, and the former of which are related through $\lambda^{k}$, that also have the property that the global market clearing condition 7 also holds. In this case, conventional trade balance conditions in goods will not hold for each country because the exporter of banking services finances a goods trade deficit through these exports, and the banking services importer generates a goods trade surplus to finance these imports.

The effects of trade liberalization in banking services on resource allocation and welfare can differ in this model relative to a more conventional no-transactions-costs model. Here the outcome is ambiguous because gains from trade are juxtaposed with increased resource use in intermediation activities that directly generate no welfare. The outcome depends on the configuration of initial endowments, consumption patterns, and the volumes of desired transactions, with resource use in transaction costs depending on the pattern of transactions between agents.

\section{NUMERICAL EXAMPLES OF WELFARE-WORSENING AND WELFARE-IMPROVING TRADE LIBERALIZATION IN BANKING SERVICES}

Using the framework described above, we have constructed numerical examples that show how free international trade in banking services can be either globally welfare-worsening or welfare-improving. As we note in our Introduction, in an equilibrium model with costly marketing of the form developed by Foley, it is possible that such cases can occur. Our numerical examples reported in Tables 1 and 2 merely confirm this intuition.

Each example involves a model with CES preferences, and two countries (Home, $H$, and Foreign, $F$ and two time-dated consumption goods, $c_{1}$ and $c_{2}$ ). Intermediation cost margins of 3 percent and 2 percent are assumed, somewhat arbitrarily, for countries $H$ and $F$, respectively. Our procedure follows the same approach as in the applied general equilibrium literature of calibration of a model to an initial microconsistent equilibrium data set, followed 
Table 1: An Example of Welfare-Worsening Liberalization in Banking Services (Two Periods, Two Countries, Two Consumers)

Welfare impacts of liberalization*

(Hicksian equivalent variations as \%

Base case data for calibration of base case household income)

a. Endowment pattern

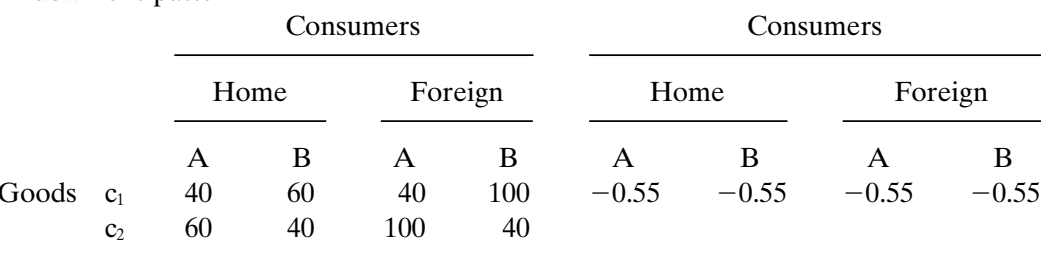

b. Consumption pattern

(Net of Transactions Costs)

\begin{tabular}{|c|c|c|c|c|c|}
\hline & \multicolumn{4}{|c|}{ Consumers } \\
\hline & & \multicolumn{2}{|c|}{ Home } & \multicolumn{2}{|c|}{ Foreign } \\
\hline & & A & B & A & B \\
\hline \multirow[t]{2}{*}{ Goods } & $c_{1}$ & 59.7 & 39.7 & 99.4 & 39.4 \\
\hline & $c_{2}$ & 39.7 & 59.7 & 39.4 & 99.4 \\
\hline
\end{tabular}

c. Assumed intermediation cost margins:

$$
\lambda_{H}=3 \% \quad \lambda_{F}=2 \%
$$

d. Elasticity configuration (CES functions)

All households in both countries have elasticities of 2.5 .

* For alternative elasticity configurations, we produce similar results. If all household elasticities are 1.0 , household losses are all $1.86 \%$ of income. If elasticities are 1.0 in the home country, and 2.5 in the foreign country, losses for all households are $0.83 \%$ of income. If these are reversed (2.5 home and 1.0 foreign), losses are $1.41 \%$ of income.

by equilibrium solution ${ }^{4}$ for a counterfactual equilibrium (see Shoven and Whalley, 1984). In this case the initial equilibrium involves autarky in banking services, while the counterfactual equilibria each involve free trade in banking services.

The data we use to calibrate our model so as to produce a welfare-worsening result for banking liberalization are presented in Table 1. An endowment pattern, a consumption pattern in the base case, an elasticity configuration, and intermediation cost margins are all assumed. Other preference parameters are implied

\footnotetext{
${ }^{4}$ We use the MPS/GE equilibrium code developed by Rutherford (1988).
} 
Table 2: An Example of Welfare-Improving Liberalization in Banking Services (Two Periods, Two Countries, Two Consumers)

Welfare impacts of liberalization (Hicksian equivalent variations as \%

Base case data for calibration of base case household income)

a. Endowment pattern

\begin{tabular}{|c|c|c|c|c|c|c|c|c|c|}
\hline & \multicolumn{4}{|c|}{ Consumers } & \multicolumn{4}{|c|}{ Consumers } \\
\hline & & \multicolumn{2}{|c|}{ Home } & \multicolumn{2}{|c|}{ Foreign } & \multicolumn{2}{|c|}{ Home } & \multicolumn{2}{|c|}{ Foreign } \\
\hline & & A & B & A & B & A & B & A & B \\
\hline \multirow[t]{2}{*}{ Goods } & $\mathrm{c}_{1}$ & 60 & 40 & 60 & 40 & 0.36 & 0.36 & 0.36 & 0.36 \\
\hline & $\mathrm{c}_{2}$ & 40 & 60 & 40 & 60 & & & & \\
\hline
\end{tabular}

b. Consumption pattern

(net of transactions costs)

\begin{tabular}{|c|c|c|c|c|c|}
\hline & \multicolumn{4}{|c|}{ Consumers } \\
\hline & & \multicolumn{2}{|c|}{ Home } & \multicolumn{2}{|c|}{ Foreign } \\
\hline & & A & B & A & B \\
\hline \multirow[t]{2}{*}{ Goods } & $c_{1}$ & 69.85 & 29.85 & 29.85 & 69.85 \\
\hline & $c_{2}$ & 29.85 & 69.85 & 69.85 & 29.85 \\
\hline
\end{tabular}

c. Assumed intermediation cost margins:

$$
\lambda_{H}=3 \% \quad \lambda_{F}=2 \%
$$

d. Elasticity configuration (CES functions)

All households have elasticities of 2.5 .

by calibration. To construct this example so as to show welfareworsening liberalization for all individuals, we have fixed the consumption patterns in each region in the microconsistent equilibrium data set, and varied the endowment patterns and elasticities until we find a counterfactual equilibrium with the desired property. Each such manipulation changes the volume of trade effects from one calculation to the next and allows us to find a welfareworsening example, such as that we report. ${ }^{5}$ In this example all consumers in both countries are made worse-off by liberalization in banking services by the same proportion of income through

\footnotetext{
${ }^{5}$ See also the theoretical discussion of endowment manipulation in Postlewaite (1979).
} 
accompanying transfers between consumers. Negative welfare effects, therefore, unambiguously imply a welfare-worsening result; positive welfare effects, a welfare-improving result.

In Table 2 we also report a numerical example in which there are gains for all individuals in both countries from banking services liberalization. In this example, the endowments and preferences of all individuals are such that net trades within each country, and hence demands for intermediation services within the countries, are smaller in the base case than in example one. In this second example, liberalization in banking is welfare-improving for all individuals.

To restate our point, liberalization of trade in banking services need not be globally welfare-improving. We provide a numerical example in which liberalization of international banking services makes all individuals in all countries worse off. The implication is that the approach to service trade liberalization emphasized in the current GATT Uruguay Round negotiations may rest on weaker analytical foundations than widely thought to be the case.

\section{REFERENCES}

Foley, Dungan K. (1970) Economic Equilibrium With Costly Marketing, Journal of Economic Theory 2:276-291.

Hindley, B., and Smith, A. (1984) Comparative Advantage and Trade in Services, The World Economy 7:368-389.

Jones, R.W., and Ruane, F. (1990) Appraising the Options for International Trade in Services, Oxford Economic Papers 42:672-687.

McCulloh, R. (1990) Services and the Uruguay Round, The World Economy 13 (3):329-340.

Melvin, J.R. (1987) Services: Dimensionality and Intermediation in Economic Analysis. Institute for Research in Public Policy discussion paper, January 1987.

Melvin, J.R. (1989) Trade in Producer Services: A Heckscher-Ohlin Approach, Journal of Political Economy 97(5): October 1989.

Postlewaite, A. (1979) Manipulation via Endowments, Review of Economic Studies 46: 255-262.

Rutherford, T.F. (1988) General Equilibrium Modeling with MPS/GE. Unpublished monograph, Department of Economics, University of Western Ontario.

Ryan, C. (1990) Trade Liberalization and Financial Services. The World Economy 13(3): 349-367.

Shoven, J.B., and Whalley, J. (1984) Applied General Equilibrium Models of Taxation and International Trade: An Induction and Survey, Journal of Economic Literature 22:1007-1051. 
